\title{
Kontribusi Social Support Dan Hardiness Terhadap Academic Resilience Pada Mahasiswa Yang Mengerjakan Skripsi Di Kota Makassar
}

\author{
The Contribution of Social Support and Hardiness to Academic Resilience for Students \\ Working on Thesis in Makassar City
}

\author{
Titin Florentina P. ${ }^{{ }^{*}}$, Arie Gunawan H. Z. ${ }^{1}$, A. Kemala Andini ${ }^{1}$ \\ *Email: titin.flo@gmail.com \\ ${ }^{1}$ Program Studi Psikologi, Fakultas Psikologi, Universitas Bosowa \\ Diterima: 10 April 2021 / Disetujui: 20 Agustus 2021
}

\begin{abstract}
ABSTRAK
Penelitian ini bertujuan untuk mengetahui apakah social support dan hardiness berkontribusi terhadap academic resilience pada mahasiswa yang mengerjakan skripsi di Kota Makassar. Penelitian ini menggunakan pendekatan kuantitatif dengan populasi mahasiswa semester akhir yang mengerjakan skripsi di Kota Makassar dan berusia 18-40 tahun. Sampel dalam penelitian ini berjumlah 360 responden. Alat ukur yang digunakan yaitu skala social support yang dibuat sendiri oleh peneliti berdasarkan pada teori social support oleh Sarafino \& Smith, skala hardiness yang diadaptasi berdasarkan teori Benishek \& Lopez, dan skala academic resilience berdasarkan teori Martin \& Marsh yang dimodifikasi oleh peneliti. Data dianalisis menggunakan teknik regresi berganda dengan bantuan aplikasi SPSS 20. Hasil analisis menunjukkan bahwa social support dan hardiness berkontribusi terhadap academic resilience sebanyak $47 \%$. Sedangkan secara terpisah, penelitian ini menunjukkan bahwa social support berkontribusi terhadap academic resilience sebanyak $33.7 \%$, dan hardiness berkontribusi terhadap academic resilience sebanyak 13.2\%. Hasil analisis tersebut menunjukkan bahwa Ha diterima dan Ho ditolak. Dengan demikian terdapat kontribusi social support dan hardiness terhadap academic resilience pada mahasiswa yang mengerjakan skripsi di Kota Makassar.
\end{abstract}

Kata Kunci: Social Support, Hardiness, Academic Reselience, Skripsi, Makassar

\section{ABSTRACT}

This study aims to determine whether social support and hardiness contribute to academic resilience in students working on thesis in Makassar City. This study uses a quantitative approach with a population of final semester students working on thesis in Makassar City and aged 18-40 years. The sample in this study amounted to 360 respondents. The measuring instrument used is the social support scale which was made by the researcher based on the social support theory by Sarafino \& Smith, the hardiness scale adapted based on the Benishek \& Lopez theory, and the academic resilience scale based on the Martin \& Marsh theory modified by the researcher. The data were analyzed using multiple regression techniques with the help of the SPSS 20 application. The results of the analysis showed that social support and hardiness contributed to academic resilience as much as $47 \%$. Meanwhile, separately, this study shows that social support contributes to academic resilience as much as $33.7 \%$, and hardiness contributes to academic resilience as much as $13.2 \%$. The results of the analysis show that Ha is accepted and Ho is rejected. Thus, there is a contribution of social support and hardiness to academic resilience for students working on thesis in Makassar City.

Keywords: Social Support, Hardiness, Academic Resilience, Thesis, Makassar

(c) $\underset{\mathrm{Br}}{\text { (i) }}$ This work is licensed under Creative Commons Attribution License 4.0 CC-BY International license 


\section{A. PENDAHULUAN}

Pembelajaran andragogi

memandang orang dewasa sebagai orang yang memiliki kemampuan dan aktif dalam merencanakan arah belajar, memiliki bahan belajar, memikirkan cara terbaik untuk belajar, menganalisis dan menyimpulkan serta mampu mengambil manfaat dari belajar atau dari sebuah proses pendidikan, sehingga fungsi pengajar hanya sebagai fasilitator dan bukan menggurui. Oleh karena itu, relasi antara guru dan peserta didik lebih bersifat multicommunication (Knowles, 1950). Pembelajaran andragogi yang diterapkan di perguruan tinggi menuntut mahasiswa untuk mandiri dalam proses belajarnya, termasuk ketika mahasiswa menghadapi masalah, kesulitan, maupun tantangan-tantangan.

Academic resilience membantu mahasiswa dalam beradaptasi positif pada hal-hal yang tidak menyenangkan yang terjadi selama proses mengerjakan skripsi. Academic resilience yang tinggi pada seorang mahasiswa akan membantunya dalam menghadapi berbagai kesulitan yang dihadapi untuk tetap mengerjakan skripsi.

Banyaknya kondisi yang tidak menyenangkan dalam penyusunan skripsi, maka dianggap perlu bagi mahasiswa membangun academic resilience. Academic resilience juga dipandang penting untuk dimiliki bagi mahasiswa karena dapat membantu mengatasi berbagai pengalaman negatif yang menekan dan menghambat selama proses belajar, sehingga berhasil memenuhi setiap tuntutan akademik dengan baik. Hasil penelitian menunjukkan bahwa setiap dimensi academic resilience dapat menurunkan stres pada mahasiswa sekolah tinggi kedinasan (Septiani \& Fitria, 2016). Hal ini mengimplikasikan pentingnya academic resilience pada mahasiswa.

Menteri Ristek dan Dikti no.44 Tahun 2015 pada bagian standar nasional pendidikan, memaparkan bahwa untuk memenuhi capaian pembelajaran lulusan program maka mahasiswa wajib menempuh beban belajar maksimum dalam masa studi tujuh tahun. Selain itu, mahasiswa strata satu juga dituntut untuk menguasai konsep teoritis bidang pengetahuan dan keterampilan tertentu secara umum dan konsep teoritis bagian khusus dalam bidang pengetahuan dan keterampilan tersebut secara mendalam.

Hasil penelitian yang dilakukan oleh Azzahra (2017) menunjukkan bahwa tingkat academic resilience pada mahasiswa semester awal memiliki 
academic resilience yang lebih tinggi dibandingkan dengan mahasiswa semester lanjut, dalam artian sedang menyusun skripsi. Hal ini sesuai dengan hasil wawancara yang dilakukan oleh peneliti.

Hasil dari wawancara peneliti dengan beberapa mahasiswa yang sedang menyusun skripsi dari beberapa universitas di Kota Makassar, bahwa mereka merasa tertekan karena kedua orangtua terus menanyakan dan menututnya untuk sarjana sesegera mungkin, teman-teman yang selalu bertanya kapan selesai yang kemudian seringkali membuat mereka down. Selain itu mereka juga merasakan kesulitankesulitan lain seperti mencari variabel yang tepat untuk dipasangkan dengan variabel utama dan sulitnya merangkai kata-kata (paraphrasing), sulitnya mendapatkan referensi-referensi yang mewakili, proses revisi yang terusmenerus, dan ada dosen yang memberikan feedback dalam beberapa bulan sehingga mereka sudah kurang motivasi untuk menyelesaikannya karena terlambat menerima feedback dari dosen yang bersangkutan.

Ada dua faktor yang dapat meningkatkan resilience pada individu, yaitu faktor resiko dan faktor protektif (Mansfield, Beltman, Price, \&
McConney, 2012). Salah satu faktor protektif sosial academic resilience adalah dukungan sosial atau social support. Social support menggambarkan hubungan individu dengan lingkungan sosialnya (Mansfield, Beltman, Price, \& McConney, 2012). Hubungan ini melibatkan berbagai aspek dukungan yang diterima individu satau komunitas dari orang lain dan lingkungan sosial yang lebih luas. Seseorang yang memiliki social support tinggi akan membantunya dalam menghadapi berbagai keadaan sulit karena hal itu akan membuat dirinya merasa tidak sendirian, selain itu kesulitan yang sedang dihadapi akan jauh lebih ringan. Salah satunya dengan memberikan dukungan informatif berupa nasehat, petunjuk, saran ataupun umpan balik dari orang-orang terdekat bisa menguatkan diri dalam mencapai sesuatu (King, 2010).

Sebagaimana hasil wawancara yang dilakukan oleh peneliti dengan beberapa mahasiswa yang mengerjakan skripsi di Kota Makassar. Mereka mengatakan bahwa dukungan dari orang-orang terdekat penting untuk meningkatkan semangat dalam mengerjakan skripsi. beberapa dari mereka mengatakan butuh orang-orang dekat yang bahkan bisa menjadi alarm untuk selalu mengerjakan skripsi. Selain itu, dukungan dari orang 
terdekat juga dapat berupa bantuan seperti saling berbagi referensi, bertukar pikiran dan diskusi mengenai masalah penelitian, dapat juga berupa material, dan sebagainya.

Beberapa hasil penilitian juga menunjukkan pengaruh hardiness pada academic resilience. Bonanno (2004) berpendapat bahwa ada beberapa jalur menuju Academic resilience di bawah tekanan, dan dia mengidentifikasi kepribadian hardiness sebagai salah satunya. Presentasinya tentang hardiness secara akurat menekankan sikap komitmennya yang saling terkait, kontrol, dan tantangan. Menyimpulkan dari berbagai teori, penelitian, dan praktik selama periode waktu ini, Maddi (2002) mengatakan bahwa hardiness sama dengan keberanian dan motivasi untuk menghadapi stressor secara dengan baik. Keberanian dan motivasi ini mengarah kepada mengatasi dan memecahkan masalah, berinteraksi dengan orang lain, mendapat bantuan dan dorongan daripada menghindari dan menyerang.

Berdasarkan uraian fenomena dan masalah di atas, peneliti tertarik untuk meneliti mengenai apakah ada kontribusi social support dan hardiness terhadap academic resilience pada mahasiswa yang mengerjakan skripsi.
Academic resilience merupakan kemampuan untuk menghadapi kejatuhan (setback) juga stres atau tekanan secara efektif dalam konteks akademik (Martin \& Marsh, 2003). Tidak berbeda jauh dari pengertian resiliency secara umum, academic resilience adalah kapasitas individu untuk bangkit, pulih, dan berhasil beradaptasi dalam kesulitan, dan mengembangkan kompetensi sosial, akademik, dan keterampilan untuk terlepas dari stres yang dihadapinya.

Dimensi academic resilience pertama kali dikemukakan oleh Martin \& Marsh (2003) dalam hasil penelitiannya; Self-belief adalah keyakinan dan kepercayaan individu pada kemampuan mereka, control adalah kemampuan siswa saat mereka yakin mengenai cara melakukan pekerjaan dengan baik, composure terdiri dari dua bagian yaitu perasaan cemas dan khawatir, dan commitment yaitu kemampuan siswa untuk terus berusaha menyelesaikan jawaban untuk memahami masalah yang mudah, sulit, bahkan keadaan yang penuh tantangan.

Social support merujuk pada kenyamanan, kepedulian, penghargaan, atau bantuan yang tersedia untuk seseorang dari orang atau kelompok lain. Social support bisa saja berasal dari 
banyak sumber, seperti pasangan atau kekasih, orang lain, keluarga, teman, dokter, bahkan organisasi atau komunitas (Sarafino \& Smith, 2011).

\section{Sarafino \& Smith (2011)} mengemukakan empat dimensi social support; (1) dukungan emosional adalah suatu bentuk dukungan yang diekspresikan melalui empati, perhatian, kasih sayang dan kepedulian terhadap individu lain, (2) dukungan penghargaan adalah suatu bentuk dukungan yang terjadi melaui ekspresi seseorang dengan menunjukan suatu penghargaan positif terhadap individu, dukungan atau persetujuan tentang ide-ide atau perasaan, (3) dukungan instrumental adalah bentuk dukungan langsung yang diwujudkan dalam bentuk bantuan material atau jasa yang dapat digunakan untuk memecahkan masalah-masalah secara praktis, dan (4) dukungan informasi adalah suatu dukungan yang diungkapkan dalam bentuk pemberian nasehat/saran, penghargaan, bimbingan/ pemberian umpan balik, mengenai apa yang dilakukan individu, guna untuk memecahkan masalah yang dihadapi.

Hardiness menurut Kobasa (dalam Smith, 1993) merupakan suatu konsep kepribadian yang khas dan unik yang didasarkan pada daya tahan atau ketabahan seseorang terhadap masalahmasalah yang dialaminya. Hardiness tersusun atas tiga dimensi; pengendalian VS ketidakberdayaan. Pengendalian merupakan kecenderungan untuk menerima dan percaya bahwa individu dapat kejadian dengan pengalamannya apabila berhadapan dengan hal-hal yang tidak terduga, sedangkan ketidakberdayaan merupakan perasaan pasif yang dimiliki individu, (2) keterlibatan VS pengasingan. keterlibatan yaitu kecenderungan individu untuk terlibat dalam segala hal seperti aktivitas, orang-orang, maupun peristiwa-peristiwa dalam kehidupannya, sedangkan individu dengan keterasingan akan mudah bosan dan merasa tidak berarti, menarik diri terhadap tugas-tugas yang harus dikerjakan, pasif, dan lebih suka menghindar dari berbagai aktivitas, (3) tantangan VS ancaman. Tantangan yaitu kecenderungan individu untuk memandang suatu perubahan sebagai sesuatu yang normal dalam kehidupan dan merupakan kesempatan untuk tumbuh dan berkembang, dan bukannya sebagai ancaman, sedangkan individu dengan perasaan terancam menganggap segala sesuatu harus stabil dan ketika terjadi perubahan maka individu tersebut akan merasa khawatir dan menganggap 
perubahan tersebut sebagai ancaman dan bukan sebagai tantangan bagi dirinya.

Berdasarkan UU Republik Indonesia nomor 12 tahun 2012 ayat 5 menyatakan bahwa mahasiswa adalah peserta didik pada jenjang Pendidikan Tinggi. Mahasiswa adalah seseorang yang sedang berada dalam proses menimba ilmu ataupun belajar dan terdaftar sedang menjalani pendidikan pada salah satu bentuk perguruan tinggi, yang terdiri dari akademik, politeknik, sekolah tinggi, institut maupun universitas. Mahasiswa memiliki rentang usia 18-25 tahun. Mahasiswa yang berada di semester I-V berada pada rentang usia 18-20 tahun dan mahasiswa akhir berada pada rentang usia 21-25 tahun. Mahasiswa masuk dalam kategori perkembangan dewasa dini. Menurut Hurlock (2017) masa dewasa dini dimulai pada usia 18-40 tahun.

Skripsi merupakan karya ilmiah yang ditulis mahasiswa program strata satu yang membahas topik atau bidang tertentu berdasarkan hasil kajian pustaka yang ditulis oleh para ahli sebelumnya, hasil penelitian lapangan, atau hasil pengembangan atau eksperimen (Huda, 2011). Dalam pengerjaan skripsi, mahasiswa dibimbing oleh minimal dua dosen yang ditunjuk atau ditentukan oleh kaprodi masing-masing fakultas.
Penulisan skripsi juga dapat berperan sebagai pendalaman displin ilmu karena selama proses penyusunan skripsi mahasiswa dituntut untuk membaca literatur dan sumber pustaka yang banyak. Menyusun skripsi dianggap penting karena nilai kelulusan studi akan ditentukan oleh kualitas isi dan penyampaian skripsi yang telah disusun oleh mahasiswa karena skripsi merupakan karya akhir dalam menyelesaikan studi strata satunya.

\section{B. METODE PENELITIAN}

Jenis penelitian yang akan digunakan dalam penelitian ini adalah metode penelitian kuantitatif. Adapun variabel bebas (independent variabel) yang digunakan dalam penelitian ini adalah social support dan hardiness (X), sedangkan variabel terikat (dependent variabel) dalam penelitian ini adalah academic resilience (Y).

Populasi yang akan digunakan pada penelitian ini adalah mahasiswa tingkat akhir yang mengerjakan skripsi di Kota Makassar. Teknik penentuan sampel yang peneliti gunakan yaitu sampling insidental, dan jumlah sampel ditentukan berdasarkan tabel krejcie dengan taraf kesalahan 5\%, yaitu sebanyak 349 sampel (Sugiyono, 2016). 
Adapun kriteria sampel penelitian ini, yaitu:

a) Mahasiswa di salah satu perguruan tinggi di Kota Makassar

b) Berada pada semester 7-14

c) Berusia 18-40 tahun

d) Mahasiswa tingkat akhir yang mengerjakan skripsi atau sedang mengambil mata kuliah "Seminar Proposal / Skripsi”.

Penelitian ini akan menggunakan tiga skala: (1) skala academic resilience yaitu academic resilience scale oleh Martin \& Marsh (2003) yang terdiri dari 15 aitem. Hasil koefisien reliabilitas skala academic resilience sebesar $\alpha=0.879$, (2) skala social support yang disusun berdasarkan teori Sarafino \& Smith (2011) yang terdiri dari 30 aitem. Hasil koefisien reliabilitas skala social support sebesar $\alpha=0.948$, dan (3) skala hardiness yang disusun oleh Benishek \& Lopez (2001) yang berangkat dari teori hardinesss Kobasa (1982), terdiri dari 19 aitem. 0.615. Hasil koefisien reliabilitas skala hardiness sebesar $\alpha=0.615$

Analisis data yang digunakan dalam penelitian ini adalah uji asumsi yang terdiri dari uji normalitas, uji linearitas, dan uji multikolinearitas. Sedangkan untuk uji hipotesis akan menggunakan analisis regresi ganda dengan dua prediktor.

\section{HASIL DAN PEMBAHASAN}

Analisis Hal tersebut juga ditunjukkan dengan persentase sumbangan efektif yang diberikan social support dan hardiness terhadap academic resilience sebesar $47 \%$, dengan nilai $\mathrm{R}$ square sebesar 0.470. Hal tersebut menunjukkan bahwa Ho ditolak dan $\mathrm{Ha}$ diterima, yang artinya terdapat kontribusi social support dan hardiness terhadap academic resilience pada mahasiswa yang mengerjakan skripsi di Kota Makassar.

Hasil penelitian ini membuktikan bahwa teori yang dikemukakan Masten (2001) benar adanya. Dalam teorinya, Masten menekankan resiliency mencakup interaksi antara individu dan lingkungannya dan menyoroti fakta bahwa faktor perlindungan tidak hanya mencakup karakteristik individu tetapi juga sosial lingkungan, seperti dukungan keluarga, teman sebaya atau komunitas. Di mana hasil penelitian ini menunjukkan kontribusi social support terhadap academic resilience sebanyak $33.7 \%$ dengan nilai signifikansi 0.000 yang berarti signifikan atau ada pengaruh.

Adanya social support yang diterima mahasiswa yang mengerjakan skripsi membuat mereka merasa dicintai, 
dihargai, dan merupakan bagian dari kelompok yang dapat menolongnya ketika membutuhkan bantuan. Sehingga beban akademik, dalam hal ini pengerjaan skripsi, yang mereka rasakan dapat menjadi lebih ringan. social support dapat berasal dari berbagai sumber seperti pasangan atau kekasih, orang lain, keluarga, teman, dokter, bahkan organisasi atau komunitas (Sarafino \& Smith, 2011). Dengan demikian, mahasiswa tingkat akhir meningkatkan academic resilience yang dimiliki dengan banyaknya social support yang dirasakan. Hasil penelitian ini mendukung bahwa social support berkontribusi terhadap peningkatan academic resilience.

Sebagaimana hasil penelitian dari Smith \& Renk (2007) yang mengatakan social support yang diberikan oleh orangorang yang berarti dalam hidup dapat menjadi predictor terhadap stres akademik yang dirasakan. Terdapat banyak hal yang bisa mempengaruhi social support seperti kebutuhan fisik, kebutuhan sosial, dan kebutuhan psikis. Seseorang yang sedang menghadapi masalah baik ringan maupun berat, maka orang tersebut akan lebih cenderung mencari dukungan sosial dari orang-orang sekitar (Sarafino \& Smith, 2011). Subjek dalam penelitian ini yaitu mahasiswa yang mengerjakan skripsi, yang mana dalam proses pengerjaannya tentu menghadapi berbagai rintangan, sehingga mahasiswa skripsi cenderung akan mencari social support. Social support yang diterima dari berbagai sumber akan membuat individu merasa diperhatikan dan merasa dicintai sehingga dapat memunculkan keyakinan akan kemampuan yang dimiliki, dan ketika mahasiswa merasa yakin akan kemampuan yang dimiiliki maka mereka akan mengerahkan segala usaha untuk menyusun skripsinya dengan baik sehingga mahasiswa dapat menyelesaikan skripsinya dengan baik dan tepat waktu. Sebagaimana hasil penelitian $\mathrm{Li}$, etc. (2018) bahwa social support dapat membantu meningkatkan harga diri siswa dan dengan demikian membantu mereka memperoleh prestasi akademik yang lebih baik.

Hal ini juga sejalan hasil penelitian dari Astuti \& Hartati (2013) yang menjelaskan bahwa social support yang diberikan orang-orang tersebut bisa membuat mahasiswa skripsi tidak berlalut-larut dalam kesulitan yang dialami dan juga bisa membantu mahasiswa mencari jalan keluar sendiri atas masalah yang dihadapi. Dalam penelitiannya menjelaskan lebih lanjut bahwa komunikasi yang baik antara dosen 
pembimbing dan mahasiwa skripsi merupakan landasan penting dalam pemberian social support.

Mohatashami, Tajari, \& Rad (2014) dalam penelitianya di Kashan University, hasilnya menunjukkan bahwa hardiness mampu memprediksi academic resilience secara positif dan signifikan, lebih lanjut menguraikan bahwa satu unit perubahan skor pada hardiness akan menyebabkan 0.34 perubahan skor pada academic resilience. Ketika individu memiliki hardiness maka besar kemungkinan individu tersebut mudah menjadi resilience, karena hardiness telah dianggap sebagai jalan menuju resilience meskipun di bawah tekanan (Maddi, 2005). Hasil penelitian ini menunjukkan bahwa hardiness memberikan kontribusi sebanyak $13.2 \%$ terhadap academic resilience mahasiswa yang mengerjakan skripsi di Kota Makassar.

Ketika mahasiswa skripsi memiliki hardiness yang tinggi maka mereka akan mudah mengontrol diri mereka untuk tidak mudah merasakan atau mengalami stres terhadap masalah-masalah yang dihadapi selama proses pengerjaan skripsi, mereka juga berkomitmen dengan apa yang mereka kerjakan, hadir dalam setiap jadwal bimbingan dan tetap berusaha menyelesaikan tugas skripsi meskipun sulit, dan kesulitan-kesulitan yang ada selama proses pengerjaan skripsi dianggap sebagai tantangan.

Maddi \& Khoshaba mengatakan bahwa individu dengan kepribadian tahan banting (hardiness) mempunyai kontrol diri, komitmen, dan mampu menghadapi tantangan sehingga apabila terjadi perubahan-perubahan di dalam maupun di luar dirinya akan dilihat sebagai suatu kesempatan untuk tumbuh dan bukan sebagi ancaman bagi dirinya. Sehingga dengan adanya 3C (control, commitment, dan challenge) pada diri mahasiswa skripsi, mereka mudah untuk menjadi resilience yaitu beradaptasi positif dengan semua kesulitan yang dihadapi. Dengan kata lain, individu yang hardiness cenderung mampu beradaptasi dengan baik, sehingga dapat memunculkan resiliensi dalam dirinya (Reivich \& Shatte, 2002). Sebagaimana yang dikemukakan oleh Hendriani (2018) dalam bukunya bahwa academic resilience berperan dalam membantu mahasiswa mengatasi tantangan dalam menyusun skripsi, hambatan-hambatan yang dihadapi, hingga mereka mampu beradaptasi dan melaksanakan setiap prosesnya dengan baik.

Berdasarkan data hasil penelitian ini, kategorisasi academic resilience pada 
mahasiswa yang mengerjakan skripsi di Kota Makassar memiliki academic resilience yang berada dalam kategori sedang yaitu dengan persentase $46 \%$. Hal ini dapat diartikan bahwa rata-rata mahasiswa yang mengerjakan skripsi di Kota Makassar cenderung mampu beradaptasi secara positif terhadap kesulitan-kesulitan yang dihadapi selama proses pengerjaan skripsi. Sebagaimana yang dikatakan Hendriani (2018) bahwa academic resilience berperan agar individu bisa beradaptasi terhadap situasisituasi negatif atau tantangan yang dihadapi selama berstatus siswa, pelajar, atau mahasiswa yang dapat menekan bahkan menghambat (Hendriani, 2018).

Dalam hasil penelitian ini diperoleh bahwa sebanyak 81 orang yang memiliki academic resilience yang tinggi (23\%). Hal ini menggambarkan bahwa mahasiswa skripsi dengan academic resilience tinggi percaya dengan dirinya sendiri bahwa mereka mampu menyelesaikan skripsi dengan baik, skripsi tidak lagi menjadi beban bagi mereka. Ketika mengerjakan tugas skripsi yang sangat sulit, mereka akan menganggap itu sebagai tantangan. Mahasiswa yang resilience secara akademik tidak mudah putus asa dalam menghadapi kesulitan akademik.
Sebagaimana Chermes, Hu, \& Garcia (2001) mengatakan bahwa individu akan merasa optimis dan berpikir positif meski sedang menghadapi kesulitan akademik karena ia percaya bahwa pasti ada jalan keluar atas kesulitan yang dihadapi.

Kesulitan-kesulitan yang dihadapi individu yang resilience justru memandangnya sebagai tantangan untuk segera menyelesaikannya. Kesulitankesulitan yang dihadapi berperan sebagai pendorong individu untuk mengerahkan segenap potensi agar kompetensinya semakin berkembang. Academic resilience terjadi ketika mahasiswa skripsi menggunakan kekuatan internal maupun kemampuan eksternalnya, seperti mampu memotivasi diri sendiri ketika mulai putus asa, perasaan self-worth atau percaya diri bahwa ia mampu menyelesaikan skripsi dengan baik, dan mandiri untuk mengatasi berbagai pengalaman negatif yang dialami selama proses pengerjaan skripsi.

Pengalaman atau situasi yang menekan dan menghambat selama proses belajar sehingga mereka mampu beradaptasi dan melaksanakan setiap tuntutan akademik dengan baik, dalam hal ini penyelesaian skripsi. Mahasiswa yang resilience adalah mereka yang berhasil mengatasi berbagai macam resiko selama proses belajar dengan cara-cara yang 
adaptif, selain itu individu yang resilience secara akademik juga tidak hanya berhasil atau mampu dalam mengatasi kesulitan yang dihadapi selama proses belajar namun juga mampu memenuhi tuntutan sosial lainnya (Boatman, 2014).

\section{KESIMPULAN DAN SARAN}

Hasil penelitian dan pembahasan dapat ditarik kesimpulan bahwa social support, hardiness dan academic resilience pada mahasiswa yang mengerjakan skripsi di Kota Makassar menunjukkan tingkat social support yang sedang. Terdapat kontribusi yang signifikan social support dan hardiness terhadap academic resilience pada mahasiswa yang mengerjakan skripsi di Kota Makassar. Dengan adanya social support dan hardiness, mahasiswa yang mengerjakan skripsi di Kota Makassar akan menjadi lebih resilience secara akademik.

\section{DAFTAR PUSTAKA}

Dukungan Sosial Pada Mahasiswa yang sedang Menyusun Skripsi (Studi Fenomenologis Pada Mahasiswa Fakultas Psikologi Undip). Jurnal Psikologi Undip, 12 (1), 69-81.

Azzahra, F. (2017). Pengaruh Resiliensi Terhadap Distres Psikologis pada Mahasiswa. Jurnal Ilmiah Psikologi Terapan, 5 (1), 80-96.

Benishek, L. A., \& Lopez, F.G. (2001). Development and Initial Validation of a Measure of Academic
Hardiness.Journal of Career Assesment, 9 (4), 333- 352.

Boatman, M. (2014). Academically Resilient Minority Doctoral Students Who Experienced Poverty and Parental Substance Abuse. Walden University Scholar Works.

Bonanno, G. A. (2004). Loss, Trauma, and Human Resilience: Have We Underestimated the Human Capacity to Thrive After Extremely Aversive Events? American Psychological Association, S (1), 101-113.

Chermes, M.M., Hu, L., \& Garcia, B. F.( 2001). Academic Self-Efficacy and First- Year College Student Performance and Adjustment. Journal of Educational Psychology, 93, 55-64.

Hendriani, W. H. (2018). Resiliensi Psikologi Sebuah Pengantar. Prenadamedia Group: Jakarta Timur.

Huda, M. (2011). Perkembangan keilmuan di STAIN Ponorogo. Jurnal Dialogia, 9 (2), 111-117.

Hurlock, E. B. (2017). Psikologi Perkembangan: Suatu Pendekatan Sepanjang Rentang Kehidupan. Erlangga: Jakata.

King, L. A. (2010). Psikologi Umum Sebuah Pandangan Apresiatif. Jakarta: Salemba Humanika.

Knowles, M., (1950). Informal Adult Education: A Guide For Administrator, Leader and Teachers. New York. Association Press.

Kobasa, S.C., Maddi, S.R., \& Khan, S. (1982). Hardiness and Health: A Prospective Study. Journal of Personality and Social Psychology, 1 (42), 168-177.

Li, A., Han, X., Wang, W., Sun, G., \& Cheng, Z. (2018). How social support influences university students' academic achievement and 
emotional exhaustion: The mediating role of self-esteem. Learning and Individual Differences, 61, 120-126.

Maddi, S. R. (2002). The Story of Hardiness: Twenty Years of Theorizing, Research, and Practice. Counseling Psychology Journal: Practice and Research, 54 (3), 173185.

Maddi, S. R. (2005). On Hardiness and Other Pathways to Resilience. American Psychological Association, 60 (3), 261-272.

Maddi, S., R., \& Khoshaba. D., M. (2005). Resilience at Work. New York: American Management Association.

Mansfield, C. F., Beltman, S., Price, A., \& McConney, A. (2012) Don't sweat the small stuff: Understanding teacher resilience at the chalkface. Teaching and Teacher Education, 28 (3), 357-367.

Martin, A. J., \& Marsh, H. (2003). Academic Resilience and the Four Cs: Confidence, Control, Composure, and Commitment. Sydney: Self-concept Enhancement and Learning Facilitation Research Centre.

Maryaeni, M. (2009). Bagaimana menulis Skripsi. Bumi Aksara: Jakarta.

Masten, A. S. (2001). Ordinary magic: Resilience processes in development.

American Psychologist, 56(3), 227-238.

Mohatashami, A. R., Tajari, F., Rad., M. R. A. (2015). Studying the relationship between Hardiness and Resilience Personality Traits and Academic Achievement among Students of Kashan University in 2014. Science Journal, 36 (3), 32943301.
Reivich, K., \& Shatte, A. (2002). The Resilience Factor; 7 Essential Skill For Overcoming Life's Inevitable Obstacle. New York: Broadway Books.

Sarafino, E.P., \& Smith, T.W. (2011). Health Psychology Biopsychosocial Interactions. Printed in the United States of America.

Septiani, T., \& Fitria, N. (2016). Hubungan antara Resiliensi dengan Stres pada Mahasiswa Sekolah Tinggi Kedinasan. Jurnal Penelitian Psikologi, 7 (2), 59-76.

Smith, J. C. (1993). Understanding Stress and Coping. Roosevelt University: Macmillan Publishing Company.

Smith, T., \& Renk, K. (2007). Predictors of Academic-Related Stress in College Students: An Examination of Coping, Social Support, Parenting, and Anxiety. Naspa Journal, 44 (3), 405-431.

Sugiyono. (2016). Statistika untuk Penelitian. Bandung: Alfabeta. 